\title{
The Utilization of Information Technology through Teleconference Examination for Child Victims of Crime in the Perspective Participation Rights
}

\author{
Irma Cahyaningtyas ${ }^{1}$, Adya Paramita Prabandari ${ }^{2}$, Kadek Cahya Susila Wibawa ${ }^{3}$ \\ \{irmafjr83@gmail.com ${ }^{1}$, apprabandari@gmail.com ${ }^{2}$, kadekwibawa@lecturer.undip.ac.id ${ }^{3}$ \}
}

Universitas Diponegoro, Indonesia ${ }^{1,2,3}$

\begin{abstract}
Technological developments can have an impact on legal progress, one of which is the use of teleconferences in court examinations. This can also be done when examining the witness's child. This paper is based on the issue regarding the basis of Law Number 11 of 2012 accommodating the use of information technology for examining child victims; second, regarding the examination process for child victims by using a teleconference. This paper uses a normative juridical research method, with a statute approach and a case approach. The results of the research in this paper state that the examination of the child victims can be carried out by teleconference by still paying attention to participation rights. This does not conflict with the principle of contante justitie. Examination of the child victim can be realized properly if there are facilities and infrastructure, one of which is the availability of teleconference rooms.
\end{abstract}

Keywords: An Examination of Child Victims of Crime, Teleconference, Participation Rights

\section{Introduction}

Indonesia is a democratic country based on the 1945 Constitution of the Republic of Indonesia and Pancasila. The 1945 Constitution of the Republic of Indonesia explains that Indonesia is a state based on law. Laws in Indonesia must be enforced with an equality system for the Indonesian people.

The development of science and technology at this time has developed very rapidly and can be felt by all circles of society. The era of the Industrial Revolution 4.0 at this time is a phenomenon that collaborates cyber technology and automation technology. The Industrial Revolution 4.0 is also known as the cyber-physical system. Its application concept is centered on automation. Assisted by information technology in the application process, the involvement of human workers in the process can be reduced. Thus, the effectiveness and efficiency of a work environment automatically increase. In the industrialized world, this has a significant impact on the quality of work and costs of production. But in fact, not only industry, but all levels of society can also get general benefits from this system.

The impact of the development of information technology also affects developments in the legal world. One of them is the trial process in court. The provisions for electronic criminal case examination are well known in cases conducted by children. The definition of a child according to Article 1 number 2 to 5 of Law Number 11 of 2012 concerning the Juvenile Criminal Justice System which states that: 
2) Children in conflict with the law are children who conflict with the law, children who are victims of crime, and children who are witnesses of criminal acts;

3) A child in conflict with the law hereinafter referred to as a child is a child who has reached the age of 12 (twelve) but has not reached the age of 18 (eighteen) who is suspected of committing a criminal act;

4) Children who are victims of criminal acts hereinafter referred to as child victims are children under the age of 18 (eighteen) who have suffered physical, mental, and/or economic losses due to criminal acts;

5) A child who is a witness to a criminal act hereinafter referred to as a child witness is a child under the age of 18 (eighteen) who can provide information for the investigation, prosecution, and examination in court regarding a criminal case heard, seen, and/or experience it yourself.

Based on this definition, it can be said that what is meant by children in Law Number 11 of 2012 concerning the Juvenile Criminal Justice System is not only children as perpetrators but also children of victims and children of witnesses. In a case where a child is a victim, the process of examining a child criminal case trial can be carried out without directly meeting the offender's child, namely through electronic media or teleconference.

The process of examining children's cases is possible to be carried out without meeting face-to-face to accommodate the basic rights of the child, particularly participation rights. Participation rights are one of the basic principles of children's rights contained in the Convention on The Rights of The Child in addition to the non-discrimination principle, the best interest of the child principle, the rights to life, survival, and development. Participation rights mean the rights of a child to express her/his views in all matters affecting that child.

In its development in 2019, the Supreme Court issued Supreme Court Regulation Number 1 of 2019 concerning the Administration of Cases and Trials at Courts electronically and in 2020, the Supreme Court also issued Supreme Court Regulation Number 4 of 2020 concerning Administration and Trial of Criminal Cases in Electronic Courts. The background to the issuance of this regulation is considered to be one of the steps to carry out a more modern trial examination.

The presence of an electronic judiciary greatly accommodates the interests of justice seekers, especially at this time where the Covid-19 virus has spread, which is a pandemic that has spread globally, including in Indonesia. With the outbreak of the Covid-19 pandemic, various negative impacts have been felt, one of which is the limitation of physical contact. Based on these conditions, the Supreme Court issued regulations related to the trial system conducted electronically or remotely by teleconference to prevent crowds from occurring. The Supreme Court stated that the issuance of the Supreme Court regulation regarding the provisions of this electronic trial was a tool for people who were hampered from seeking justice. This means that the implementation of judicial principles that is fast, simple, and low cost can be realized.

This paper takes issues, including first, what is the basis for Law Number 11 of 2012 to accommodate the use of information technology for examining child victims; second, how is the examination process for child victims of crime using teleconference.

Some of the previous studies that discussed the use of information technology in the legal field include articles that explain the effectiveness of the implementation of E-court to eradicate the activities of judicial corruption [1]; the next article explains the implementation of E-court in general criminal cases [2]; the next article discusses the use of video teleconferencing in asylum removal hearings as codified in 28 USC [3]. In addition, there are also articles that research how juvenile court judges take the psycho-social immaturity and development of 
adolescents into consideration when making attributions of adjudicative competency of offenders in juvenile court [4].

This paper aims to examine the use of information technology through teleconferences, especially those used for examining child victims of crime in the trial examination process while still accommodating participation rights.

\section{Research Methods}

This paper uses a normative juridical research method, which is research that is focused on examining the application of the rules or norms in positive law [5]. The approach used in this paper is a statutory approach and a case approach [6]. The statutory approach is used to analyze the rules related to the process of examining child cases, especially child victims, based on Law Number 11 of 2012 concerning the Juvenile Criminal Justice System and Supreme Court Regulation Number 4 of 2020 concerning the Administration and Trial of Criminal Cases at Courts Electronically. The case approach is used to examine the application of legal norms that exist in legal practice, especially regarding the examination of child victims of crime in the trial examination process and the adjustment of infrastructure related to the use of teleconferences.

\section{Result and Discussion}

\subsection{The Basis of Law Number 11 of 2012 concerning The Juvenile Criminal Justice System to Accommodate the Use of Information Technology for Examination of Child Victims}

Children who commit acts that violate the rules, especially causing victims to be held responsible. The state must continue to guarantee and protect children and their rights so that children can live, grow and develop, participate like children in general and avoid violence and discrimination. Therefore, the process of handling cases involving children is different from adults.

The process of examining criminal cases involving children can be carried out through nonpenal policies and penal policies. The non-penal policy is known as a diversion as regulated in Article 1 point 7 of Law Number 11 of 2012 which is a transfer of settlement of juvenile cases from the criminal justice process to the process outside the criminal court. To provide a sense of justice and prioritize children's rights, diversion must take precedence if it meets the requirements for the implementation of diversion by Article 7 paragraph (2) which states that:

2) Diversion as referred to in paragraph (1) shall be implemented in the event of a criminal act that is committed:

a. threatened with imprisonment of less than 7 (seven) years; and

b. does not constitute a repetition of a criminal act.

If an agreement is not reached, the settlement of the case is pursued by a penal process, which is the process of resolving a juvenile case that is carried out starting from the stage of the investigation, prosecution, and trial examination in court. Children's cases at the stage of 
examination in court are carried out at the Juvenile Court and children's cases are heard by a single judge, namely the Juvenile Judge.

One form of protection for the victim's child during the examination of a case by a judge, namely the trial process of children which can include an examination that adheres to the In Absentia system, namely striving to ensure that children who conflict are not attending and punishing [7].

If a child as a victim can attend the examination in court to give information, then the provisions of Article 58 paragraph (1) of Law Number 11 of 2012 concerning the Juvenile Criminal Justice System require that the child victim be able to leave the courtroom, to avoid a meeting between the child of the perpetrator to avoid the possibility of traumatizing or threatening physical or psychological harm.

On the other hand, if the victim's child is unable to attend to testify in front of the court for any reason, the judge has no right to refuse and force the child to attend. This is as stated in Article 58 paragraph (3) of Law Number 11 of 2012 concerning the Juvenile Criminal Justice System which states that:

1) If the Child Victim and/or Child Witness is unable to attend to testify before a court session, the Judge may order the Child Victim and/or Child Witness to be heard:

a. outside court proceedings through electronic recording conducted by Community Guides in the local jurisdiction in the presence of Investigators or Public Prosecutors and Advocates or other legal aid providers; or

b. through direct remote examination using audiovisual communication accompanied by a parent/guardian, social adviser or another companion.

c. According to this paper, these provisions mean that Law Number 11 of 2012 concerning the Juvenile Criminal Justice System accommodates the use of information technology through audiovisuals.

The process of investigating criminal acts is generally guided by Law Number 8 of 1981 concerning Criminal Procedure Law or the so-called KUHAP. In its implementation, the Criminal Procedure Code does not regulate the use of teleconferences. This paper argues that because the use of teleconferences when the Criminal Procedure Code was drafted and enacted was not known at that time and legislators were also unaware of the rapid development of information technology.

The trial examination process will end upon the issuance of the judge's decision. In a criminal case, a criminal judge's decision is based on material truth. Material truth is the truth that is not just based on formal truth, but the role of the judge's conviction which is based on conscience plays a very important role [8].

So that even though the examination for the child victim is carried out using a teleconference, it will not limit the judge in assessing the testimony giving through conviction based on conscience in terms of distributing material truths that lead to substantial justice.

\subsection{Examination of Child Victims of Crime by Using a Teleconference}

Juridically, trial examinations in court using information technology have not been regulated in general in Law Number 8 of 1981 concerning the Criminal Procedure Code or what is known as the Indonesian Criminal Procedure Code. There is no regulated trial examination through teleconference in the Indonesian Criminal Procedure Code, so the use of teleconference 
in the trial examination only depends on the awareness of the judge based on Article 10 paragraph (1) and Article 5 paragraph (1) of Law Number 48 of 2009 concerning Judicial Power.

The judge must examine and make a decision, which means he is obliged to find out the law. Judges can base the idea that in a society that still knows the unwritten law and there are upheavals and transitions, the judge is the formulator and explorer of values that live among the people, for that he must plunge into the community to know, feel and be able to explore the feelings of law and justice in society. Thus the judge can give a decision that is following the law and the sense of justice of the community.

One type of information technology that can be used when examining a child victim in a child trial examination is through a teleconference. Teleconferences can be carried out by two or more people through communication media, telephone, and television or computer layers that have been connected to a network connection [9].

Teleconferences can be done using only voice or known as audio conferencing or it can also allow two or more people to meet face to face in person or what is called a video conference. The use of information technology in handling cases in court can aim to assist judges and other law enforcement officers in court and create good interactions between courts and other parties, including in this case child victims.

In line with this, there is a conception of the categories of use of information technology in court, which are as follows [10]:

a. Information technology is used independently (stand-alone, function information technologies)

Courts utilize the standard functions of information technology to assist with administrative tasks (back office). In utilizing this function, there is no need for a network between computers. There are two applications commonly used by courts for this category, namely: word processing applications and databases. This word processing application is used by judges and court staff to generate case file documents. Also included in this category is the use of trial calendars and simple spreadsheets. The database application is used for registration and case management. This system replaces the manual file recording process.

b. Information technology based on network systems

Historically, network technology was introduced after the stand-alone function of the technology was used by the courts for some time. Network technology facilitates interaction between users but without any specific parameters. Users allow other users to interact but are not specified how they should interact. Utilization of network-based information technology in courts includes electronic mail, internet connection, jurisprudence database, document sharing, and electronic files. Included in this category, are network systems that combine databases and word processing applications to create standard court decision templates.

c. Enterprise external information and communication technology

Information technology in this category has implemented workflow management systems, customer relations management systems, and electronic external communications with justice seekers. The ideal model of this third category is all process management. carried out include filing files electronically, case handling is carried out with an electronic workflow system, products from the court are also in the form of electronic files. Although the trial process still maintains the physical trial, the court has left paperless files. Courts that apply enterprise information technology will be able to reorganize business processes, standardize workflows, and efficiently monitor all activities. This means that all processes can be more easily redesigned and standardized, as well as reporting can be presented at any time. 
Examination of child victim through teleconference aims to protect children's rights while still being able to provide information for the sake of evidence at court examinations. Examination of the victim's child by teleconference is carried out from where the child is located and must be accompanied by a parent/guardian, social adviser, attended by investigators or public prosecutors, and advocates using telecommunications facilities to connect with court proceedings. The juvenile court will then use a television or projector media supported by a sound system so that visually showing the child, including the child's voice, must be heard by the parties present in the courtroom. Furthermore, if the teleconference has been displayed and is functioning properly, then the examination can be started.

When viewed from the physical, psychological, and social conditions of the victim's child, in giving testimony directly at court, it cannot be forced because there is a worry, fear, trauma due to formal judicial attributes in court proceedings. This condition must be avoided by conducting a teleconference examination so that it can provide space for children who do not want to face the courtroom directly and children as victims in providing information will feel more comfortable and free. In addition, for some parties, especially parents, the presence of children as witnesses and/or as victims are avoided to prevent threats that may come from the aggrieved party.

The relatively rapid development of the law is not sufficiently regulated in legislation. For example, a teleconference that is not regulated in Indonesian Criminal Procedure Code does not mean that the provisions of Indonesian Criminal Procedure Code prohibit the use of teleconference, especially if the party being examined is a child who must receive protection [11].

According to this article, the use of teleconference in the examination of child victims does not violate the general principles applicable to criminal procedural law, in particular the principles of contante justitie, which can be described as follows:

a. The principle of contante justitie is contained in Article 50 of Indonesian Criminal Procedure Code, besides that it is also contained in Article 4 paragraph (2) of Law Number 48 of 2009 concerning Judicial Power. The principle of fast trial the definition of "quick trial" is the benchmark used based on the size of the time limit for the judicial process. Law Number 11 of 2012 concerning the Juvenile Criminal Justice System also explicitly mentions the limitation of the period in the process of examining child cases.

b. The principle of contante justitie is defined as the administration of justice in an integrated manner, the judicial process is not complicated or complicated but orderly, the judicial process is not delayed so that it takes time. This principle does not conflict with the use of teleconference to present witnesses to the trial, does not complicate the trial process because the use of this technology is very easy so that the trial can run as usual, and the procedure remains simple.

c. The principle of contante justitie is defined as the judicial process must be carried out with the minimum possible cost or low cost but material truth is still achieved. The principle of low cost can also mean that the cost of administering justice is reduced in such a way that it is affordable for justice seekers, to avoid wasting costs. By using teleconference, the parties being examined, whether witnesses and/or defendants remain in their respective places.

The use of teleconference in the examination of child victims at trial strongly adheres to the principles of contante justitie, especially in the current situation where there are applications that are easy, free, and can be used by anyone, such as Zoom, Skype and Google Plus "Hangout". Edmon Makarim said [12]:

Teleconferencing does not need to use conventional technology such as "Direct Video" or "uplink" to satellite which is indeed more expensive, but the cost is very economical but the 
same, namely with the support of computer technology, one of which is the use of Voice Over Internet Protocol (VOIP) or line Global for voice communication which is familiar in the telematics community, namely with the use of the internet, teleconferences can also be done as long as the basic network conditions are fast, good and the processor used is good through several servers with high frequency speeds as well.

According to this article, it is necessary to make legal reforms related to the regulation of the use of teleconference in the examination of child victims in criminal cases in court. The renewal can be in the form of a Supreme Court Regulation or other regulations.

The use of teleconferencing can run smoothly if it is supported by good facilities and infrastructure. This has been accommodated by the Directorate General of General Courts which issued the Decree of the Director General of General Courts Number 2176/DJU/SK/PS01/12/2017 concerning the Minimum Standard Guidelines for Child-Friendly Court Facilities and Infrastructure, which states that juvenile courts also have friendly perspective children so that one of their needs is obliged to provide a teleconference room with the following conditions:

a. The teleconference room was present as an implementation of the Juvenile Criminal Justice System Law and the Child Protection Law;

b. Tables and chairs should be made as comfortable as possible to maintain the child's psychology;

c. The available means of communication, for example, a microphone as far as possible, do not look like the interview process;

d. The teleconference room can also be used for child victims of crimes committed by adults.

There is an obligation to provide a teleconference room at each juvenile court very accommodating children's basic rights, one of which is participation rights. Participation rights, in this case, are the right to express opinions for children, especially when it comes to matters that can affect their lives. So according to this paper, one of the implementations of participation rights can be found in the examination of the victim's child at the trial level. Therefore participation rights needs to be realized, especially in every decision making.

Participation rights for the victim's child can also be seen even though the victim's child is not directly present at the examination at the court hearing, but the victim's child can still provide their testimony. Providing testimony through teleconference can indirectly protect the child's physical and psychological condition so that the traumatic condition of the victim's child will slowly disappear.

When viewed in the provisions of procedural law in effect in Indonesia, the victim's testimony is equated with the testimony of witnesses, namely witnesses who are also victims, especially those related to evidence, one of which is the power of evidence [13]. The degree of evidence witness testimony to be considered valid as evidence that has a value of the strength of evidence must meet two categories of requirements as follows:

a. Formal Terms

It is a condition that refers to the subject, namely the person who will testify.

b. Material Terms

It is a condition that refers to the contents of the statement given by the witness.

Examination of the victim's child does not contradict the power of proof. The use of teleconference, especially in examining child witnesses, the provisions that can be used as a basis for measuring the strength and assessment of evidence are regulated in Article 183 to Article 189 in conjunction with Article 3 of Law Number 8 of 1981 concerning Criminal Procedure Code. According to this paper, the proving power of a child victim as a witness who gives information by teleconference can be equalized in weight to giving testimony directly in 
front of a child judge. To use and assess the strength of evidence attached to evidence, one of which is that the testimony of the child victim must be carried out by the limits justified by law. This must be done by the judge so that the court's decision is not based on the subjectivity of the judge. By using the teleconference media, there is no need to present the victim's child in front of the trial. The examination process at trial will be simpler without eliminating any procedures, such as the general hearing process in court.

\section{Conclusion}

Law Number 11 of 2012 concerning the Juvenile Criminal Justice System has accommodated the use of information technology for examining child victims. This can be seen in the process of examining the victim's child which can be carried out outside of court through electronic recording carried out by Community Guides in the local legal area attended by Investigators or Public Prosecutors and Advocates. The remote direct examination carried out on the victim's child must be accompanied by a parent/guardian, community advisor, or another companion. The use of information technology in the examination of the victims child can be done via teleconference. The examination of the victim's child must manifest participation rights and also have the same power of proof as to the testimony that was present in the trial examination process. Another thing that needs to be considered is to provide the necessary facilities and infrastructure so that the trial examination process runs smoothly. With the accommodation of the examination of child victims, the fate of the child victims will be clearer and it will not cause protracted uncertainty caused by the course of the evidentiary process at trial in the juvenile court.

\section{Acknowledgments}

We are grateful for the collaboration of thoughts that resulted in this paper. We thank the Faculty of Law Universitas Diponegoro who have provided and financial support at 2021; Indonesian Child Protection Commission which has provided data.

\section{References}

[1] M. I. Susanto and W. Supriyatna, "Creating an Efficient Justice System with e-Court System," International Journal of Arts and Social Science, vol. 3, no. 3, pp. 354-361, 2020.

[2] A. H. Saputri, "Penerapan e-Court dalam Perkara Tindak Pidana Umum Dalam Perspektif Hukum Progresif," Jurnal Hukum dan Pembangunan Ekonomi, vol. 8, no. 1, pp. 11-22, 2020.

[3] F. M. Walsh and E. M. Walsh, "Effective Processing or Assembly -Line Justice- The Use of Teleconferencing in Asylum Removal Hearings," Geo Immigr. - HeinOnline, 22, p. 259, 2007.

[4] C. M. Berryessa and J. Reeves, "The Perceptions of Juvenile Judges Regarding Adolescent Development in Evaluating Juvenile Competency," The Journal of Criminal Law and Criminology, vol. 110, no. 3, pp. 551-592, 2020.

[5] S. Soekanto and S. Mamudji, "Penelitian Hukum Normatif, Suatu Tinjauan Singkat," Jakarta: Rajawali, 1985.

[6] N. D. M. Fajar and Y. Achmad, "Dualisme Penelitian Hukum Normatif dan Empiris," Yogyakarta: Pustaka Pelajar, 2015. 
[7] A. G. Lembong, "Kajian Hukum Terhadap Sistem Pemidanaan Anak Menurut Undang-Undang Nomor 11 Tahun 2012," Lex Crimen, vol. 3, no. 4, p. 18, 2014.

[8] A. Hamzah, "Hukum Acara Pidana Indonesia," Jakarta: Sinar Grafika, 2008.

[9] N. M. R. Meidyana and I. B. W. Putra, "Keabsahan Pemeriksaan Saksi Melalui Teleconference dalam Sidang Tindak Pidana Korupsi," Jurnal Kertha Wicara, vol 7, no. 5, pp. 1-17, 2018.

[10] D. Relling, "Technology for Justice: How Information Technology Can Support Jucicial Reform," Netherlands: Leiden University Press, 2009.

[11] S. Dewi, "Kajian Yuridis Terhadap Keterangan Saksi Melalui Audio Visual (Teleconference) di Persidangan Perkara Pidana," Jakarta: Universitas Indonesia, 2012.

[12] S. Arief, "Teleconference Lewat Skype Revolusi Digital Dunia Peradilan," 2013. [Online]. Available: https://news.detik.com/berita/d-2188082/telecoference-lewat-skype--revolusidigital-dunia-peradilan.

[13] H. Sasangka and L. Rosita, "Hukum Pembuktian dalam Perkara Pidana", Bandung: Mandar Maju, 2003. 